\title{
NOTES.
}

A NEW CORDYCEPS.-A very remarkable species of Cordyceps has just been received at the Kew Herbarium from Owen's River, Victoria, where it was discovered by Miss M. Henley. It springs from a large caterpillar, and differs from all known species in the sharply differentiated fertile branches being erumpent from a simple, vertical stroma, eight to nine inches high; also in peculiarities of the ascophore. It will be known as Cordyceps Henleyae, and will be described in detail at a later date. G. MASSEE, Kew.

\section{ABSORPTION OF WATER BY DEAD ROOTS.-Several} experiments have already been made relative to the power of dead roots to supply nourishment to plants ${ }^{1}$, leading to the conclusion that if the roots are killed without being ruptured, they may continue to take up moisture, and thus keep the plants alive for a considerable time. The matter may be roughly tested by killing the roots of the plants by immersing them for a time in boiling water, and carefully noting the results.

The following plants were experimented upon, with the result which any cultivator would have anticipated, namely, that dead roots are incapable of affording any continual sustenance to the plants to which they are attached. At the same time it is interesting to observe that in many cases the plants remained fresh for several days after their roots were killed. In every case care was taken to prevent the heat or steam from the boiling water from injuring the leaves or stems of the plants above the 'collar.' For the purpose of comparison the tops of two plants of Cassia alata were cut off level with the soil, and placed in water in the same house with those treated with boiling water. It will be seen that specimen 3, which had been severed under water remained fresh as long as the plant with boiled roots.

Cassia alata.-I. Plant in pot: roots immersed in boiling water on Feb. I6th, I893; had not suffered on 2 oth ; flagged on 23 rd; leaves

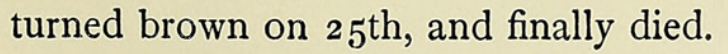

' See Strasburger, Leitungsbahnen in den Pflanzen, Histologische Beiträge, III, p. 849 , and the papers there cited. 

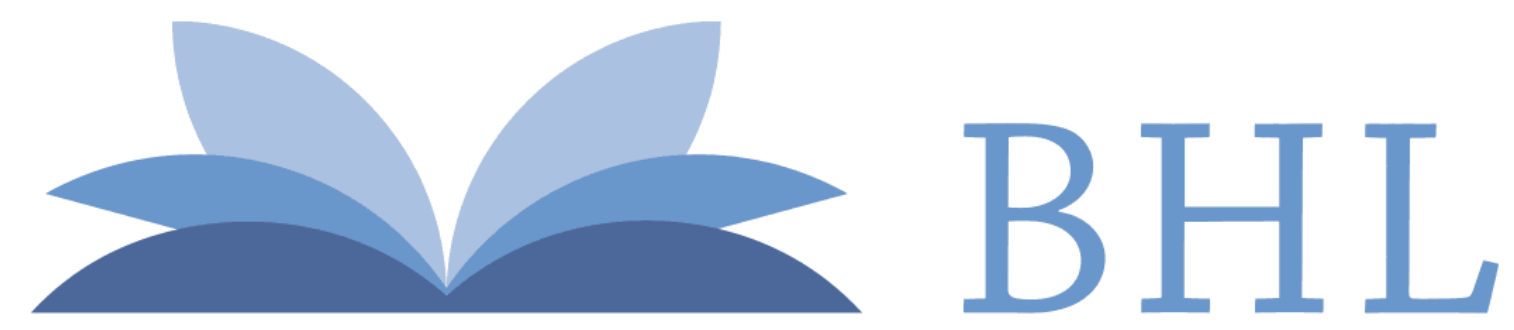

\section{Biodiversity Heritage Library}

Massee, George. 1894. "A new Cordyceps." Annals of botany 8, 119-119. https://doi.org/10.1093/oxfordjournals.aob.a090695.

View This Item Online: https://www.biodiversitylibrary.org/item/233540

DOI: https://doi.org/10.1093/oxfordjournals.aob.a090695

Permalink: https://www.biodiversitylibrary.org/partpdf/317756

\section{Holding Institution}

Smithsonian Libraries

\section{Sponsored by}

Biodiversity Heritage Library

\section{Copyright \& Reuse}

Copyright Status: Not in copyright. The BHL knows of no copyright restrictions on this item.

This document was created from content at the Biodiversity Heritage Library, the world's largest open access digital library for biodiversity literature and archives. Visit BHL at https://www.biodiversitylibrary.org. 